\title{
The Process of Cultivated Land and Water Resource Distribution Changing in Recent Decades in Upstream and Downstream in Shiyang Inland River Basin in Arid Area of Northwest China
}

\author{
Huaidong Wei ${ }^{1}$, Ya Li ${ }^{*}$, Cundong Xu${ }^{2}$, Lanping Zhou ${ }^{1}$, Xiaoke Hu${ }^{1}$, Feng Ding1, \\ Fang Chen 1 \\ ${ }^{1}$ State Key Laboratory Breeding Base of Gansu Desertification and Aeolian Sand Disaster Combating/Gansu \\ Minqin National Studies Station for Desert Steppe Ecosystem, Lanzhou, China \\ ${ }^{2}$ North China University of Water Resources and Electric Power, Zhengzhou, China \\ Email: *lygdci@126.com
}

Received 22 January 2016; accepted 26 July 2016; published 29 July 2016

\section{Abstract}

Last century 50 - 70 years, the dam construction of Shiyang Inland River Basin (SIRB) profound impact on the distribution of water resources and arable land in the basin. Through data collection, field surveys and remote sensing image interpretation, we analysis the use of land and water resources change process in the middle and lower reaches of SIRB in recent decades. The results show: (1) The cultivated area of SIRB has been an upward trend in recent decades, The whole basin cultivated area has increased total $229,000 \mathrm{hm}^{2}$ from 1973 to 2010 and mainly in the middle and lower reaches. Midstream increased by $149,700 \mathrm{hm}^{2}$ accounting for 65.36 percent of total, downstream increased by $70,000 \mathrm{hm}^{2}$ accounting for 30.70 percent of total. (2) The amount of surface water resources of downstream reduce significantly gradually since dam construction, and the water table sharp decline. While the volume of surface water resources come downstream from the 1950 s accounted for 30 to 40 percent of the total gradually reduced to less than $10 \%$ in 2012; (3) since the arable land area of middle and lower reaches of SIRB basin substantial increase, so the surface water resource does not meet irrigation needs. Agricultural irrigation relies heavily on exploitation of groundwater to supplement, resulting in Regional Groundwater Depth dropped rapidly, and forming several huge funnel groundwater settlements. 20 years from 1981 to 2001 the groundwater level of midstream dropped from around $5 \mathrm{~m}$ to around $10 \mathrm{~m}$ in Wuwei, and in Minqin dam-region of downstream along faster rate of decline in 20 years fell from $8.52 \mathrm{~m}$ to $22.68 \mathrm{~m}$. Dam construction project has changed the pattern of the basin water cycle, the middle reaches closure a large number of surface water resources led to downstream sharp decline. Downstream continued exploitation of groundwater formed a few huge funnel groundwater settlements, it caused serious ecological problems. The basin should adjust the industrial structure

\footnotetext{
${ }^{*}$ Corresponding author.

How to cite this paper: Wei, H.D., Li, Y., Xu, C.D., Zhou, L.P., Hu, X.K., Ding, F. and Chen, F. (2016) The Process of Cultivated Land and Water Resource Distribution Changing in Recent Decades in Upstream and Downstream in Shiyang Inland River Basin in Arid Area of Northwest China. Journal of Geoscience and Environment Protection, 4, 166-171. 
and develop water saving irrigation, promote a virtuous cycle of water resources, to achieve sustainable development, seek a sustainable development ways conversion natural oasis to artificial oasis efficiency in arid zone.

\section{Keywords}

\section{Shiyang Inland River Basin, Water Resources, Cultivated Area, Changes}

\section{Introduction}

Shiyang Inland River Basin (SIRB) is a water resource relatively closed inland river basin. Also is one of the major inland river basins in arid area of Northwest China. It located in the eastern part of the Hexi Corridor in Gansu Province. It is basin the most populous inland river basin in Hexi inland river basins with more developed economy. It also is the maximum utilization of land and water resources development. The water conflicts of upstream and downstream are most prominent, the most serious environmental problems in the region. Arid inland river basin has a special geographical environment; it makes a unique water circulation system of water formed during the formation, migration, conversion and consumption. The distribution of water resources in the basin directly affect the development and utilization of water and land resources, also affect the sustainable development of social and economic and a virtuous cycle of ecological environment in the basin [1]-[3] (Qi et al., 2006; Ji et al., 2008; Guo et al., 2010). From the beginning of the 1950s, People built more than 20 reservoirs in the Qilian Mountains pass and middle reaches of the river, to achieve a water allocation of human control. Coupled with population growth and policy, economic, technological stimulation open up wasteland, Basin groundwater extraction, Production and living water and agricultural water in the middle reaches exponentially since the 1970s. It causing downstream large plantations and natural vegetation reduce the arable land Stalinizations, the groundwater rapid decline, groundwater salinity Increase, The ecological environment sharp deterioration [4]-[8] (Xu et al., 1989; Xu et al., 1986; Han et al., 2008; Wang et al., 2002; Han et al., 2009). Through data collection and field investigation, we analyzed the basin water and land resources use and vegetation change process of SIRB before and after the water Reservoir Construction. This is a comprehensive assessment of the ecological effects of dam construction, for scientific planning Basin Soil and water resources development and utilization, Implementation of integrated ecological environment.

\section{Materials and Methods}

The Cultivated Land data comes from MSS (1973), Land sat TM (1987, 1994, 1998 and 2010) and CBERS (2005) interpretation results of remote sensing image classification with ERDAS software, and statistical with ARC/GIS. The total amount of Basin surface water resource is the total amount of water from the mountain pass by the all eight rivers, assigned to the downstream surface water amount is the storage water amount entering Hongyashan Reservoir of Minqin in downstream. These data come from monitoring data Hydrological Monitoring Directorate Gansu Province; Groundwater level data from the hydrogeology, mining sector in the Shiyang River Basin established observation wells 1981-2011 years of observations.

\section{Results and Analysis}

\subsection{Change Process of Cultivated Land}

The area of Cultivated Land in SIRB has been an upward trend in recent decades (Figure 1), in 1973 total of whole basin cultivated land is $470,700 \mathrm{hm}^{2}$, Wherein the upstream 105,100 $\mathrm{hm}^{2}$, Accounting for 22.33 percent of total cultivated land of whole basin; the midstream 298,100 hm², Accounting for 63.33 percent of whole basin; the downstream 67,500 $\mathrm{hm}^{2}$, Accounting for 14.34 percent of whole basin; By 2010 the cultivated area of whole basin has reached $699,800 \mathrm{hm}^{2}$, Wherein the upstream $114,100 \mathrm{hm}^{2}$, Accounting for 16.31 percent of total cultivated land of whole basin; the midstream $447,800 \mathrm{hm}^{2}$, Accounting for 63.99 percent of whole basin; the downstream 137,800 $\mathrm{hm}^{2}$, Accounting for 19.70 percent of whole basin. The cultivated land of whole basin from 


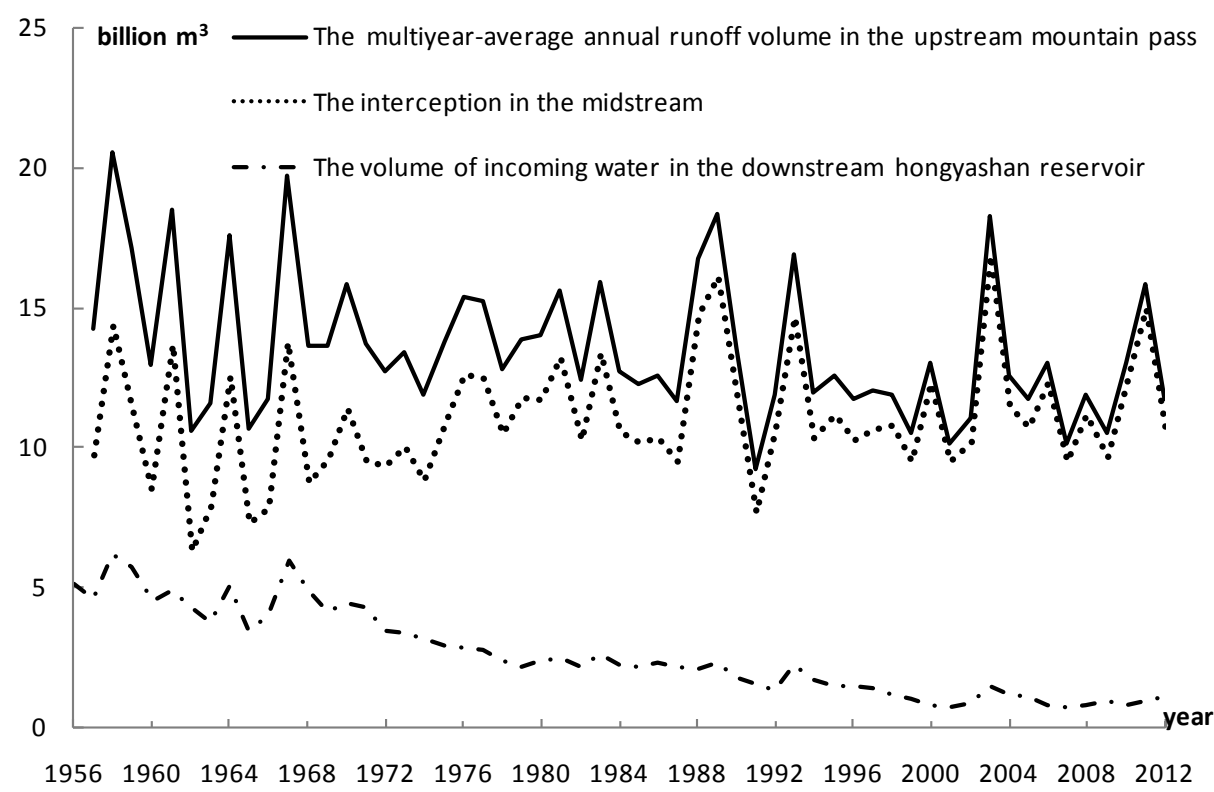

Figure 1. The total surface water and distribution between midstream and downstream from 1956 to 2012 in Shiyang river.

1973 to 2010 total increase 229,000 $\mathrm{hm}^{2}$, the main increase area located in the midstream and downstream, midstream increased by $149,700 \mathrm{hm}^{2}$ and accounting for 65.36 percent of the total increase area; downstream increased by $70,300 \mathrm{hm}^{2}$ and accounting for 30.70 percent of the total increase area; While upstream increased by only $9,000 \mathrm{hm}^{2}$ and accounting for 3.94 percent.

Cultivated area of upstream continued increase from 1973 to 1994, while 1994 to 2010 has decreased. 21 years from 1973 to 1994 increased 14,600 hm²; the 14-year main increased period 1973 to 1987 added 13,700 $\mathrm{hm}^{2}$, while the 16 years from 1994 to 2010 reduce the area of only $05,600 \mathrm{hm}^{2}$; the middle reaches cultivated area from 1973 to 2010 continued to increase, a total increase of $149,700 \mathrm{hm}^{2}$ this 37 -year period. In the 14 years from 1973 to 1987 it increased 31,300 hm², the 7 years from 1987 to 1994 it increased 16,600 $\mathrm{hm}^{2}$, and the 4 years from 1994 to 1998 increased 21,200 hm², the 7 years from 1998 to 2005 years increased 58,100 hm², the 5 years from 2005 to 2010 increased 22,400 hm²; The down reaches cultivated area from 1973 to 2005 continued to increase and this 32 years period increased $73,000 \mathrm{hm}^{2}$, while declined after 2005. 15 years from 1973 to 1987 an increase of 15,300 hm², 7 years from 1987 to 1994 increased 19,100 hm², 4 years from 1994 to 1998 increased $18,800 \mathrm{hm}^{2}, 7$ years from 1998 to 2005 increased 19,700 $\mathrm{hm}^{2}$, while during the 5 years from 2005 to 2010 reduce the area of $2600 \mathrm{hm}^{2}$.

\subsection{Change Process of Water Resources Distribution}

\subsubsection{Surface Water Resources}

SIRB has a Comparative development hydrological network; it originated North Slope of Lenglongling Mountain, all concentrated in the eastern Qilian Mountains. The more big 8 rivers in mountain pass coming from the east to the west were Dajing river, Gulang river, Huangyang river, Jingta river, Zamu river, Xiying river, Dongdahe river, Xidahe river. The years of average runoff volume of the eight rivers is 1.539 billion $\mathrm{m}^{3}$. From the data change trend analysis of runoff volume of the eight rivers from 1956 to 2012 (Figure 2), annual variability runoff process can be divided into four stages: from 1956 to 1968 belong to the overall trend downward phase, 1969-1990 belong to the overall trend of the stationary phase, from 1991 to 2002 belong to the overall trend of decline stage, in 2003-2012 belong to the overall trend of steady stage. The 30 years from 1956 to 1985 basically completed a wet period, a mean water period and a dry period cycle, from 1985 to 2012 began to enter the second cycle of the 30-year Mean water period. The wet period of the SIRB is generally 1 to 3 years, the dry period is generally 3 to 9 years, and the mean water period is generally 15 to 20 years. Chance each year of the emergence of the largest is the mean water period, the dry period followed by and the wet period at least. Such 


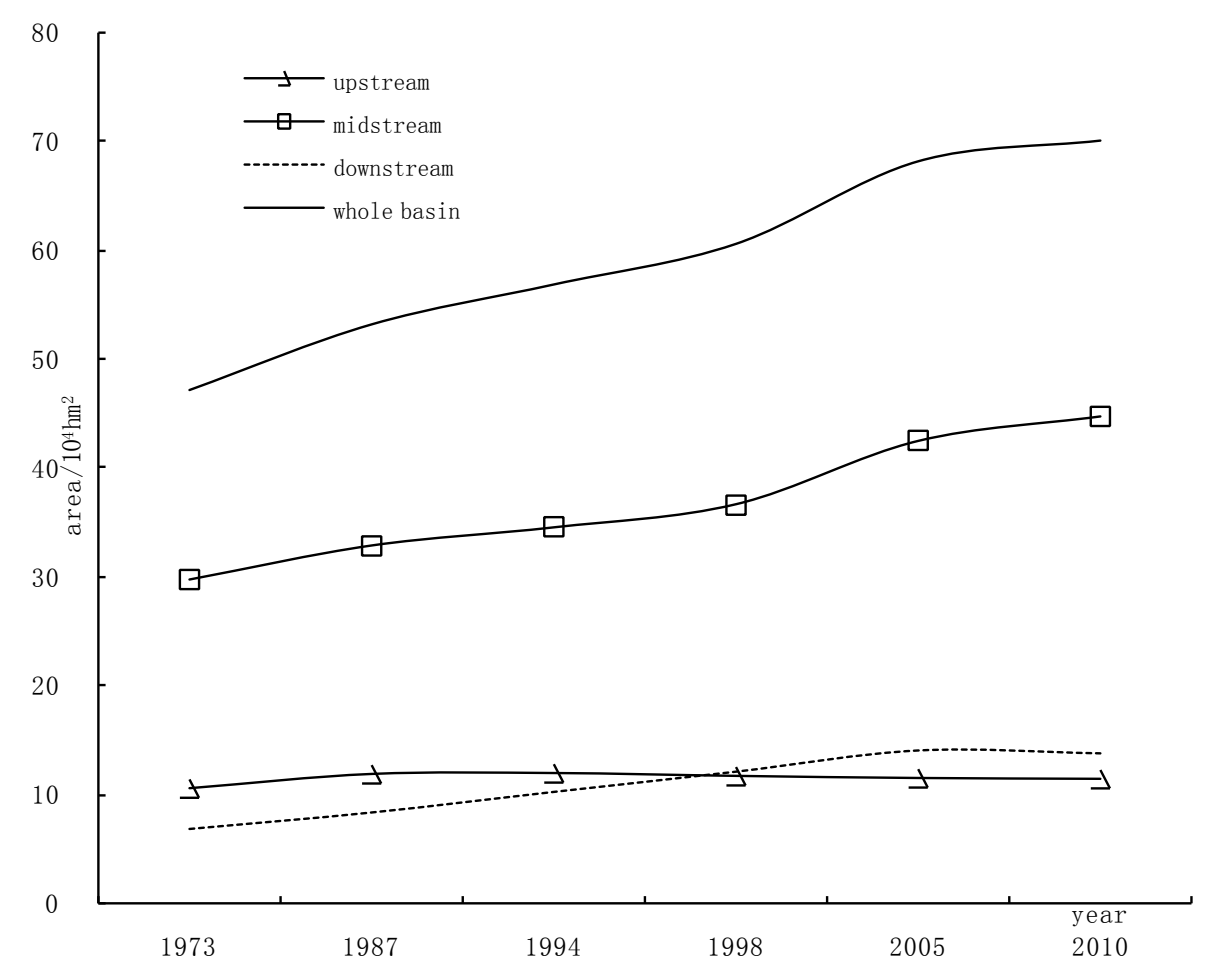

Figure 2. The change of area of cultivated land from 1973-2010 in Shiyang inland river basin.

as 1968-1988 mean water period lasted 20 years; in 1994-2002 the Dry period lasted 9 years. From runoff water data, most of the time in the mean and dry state, it can be seen drought and water shortage within the hydrological phenomena is the laws of nature in the SIRB.

The total amount of surface water resource in the mount pass of River Basin is limited, but a large number of surface water resources were interception to irrigation in midstream result into the runoff volume to downstream Hongyashan reservoirs decreasing (Figure 2). Midstream interception water from 1956 to 1969 accounted for $60 \%$ to $70 \%$ of the total, from 1970 to 1975 is 70 to $80 \%, 1976$ to 1987 more than $80 \%$, between 80 to $85 \%$,from 1988 to 1999 reached $85 \%$ to $90 \%$, from 2000 to 2012 more than $90 \%$ between 90 to $94 \%$. The amount of surface water Reach downstream gradually reduce from the 1950s accounted for 30 to 40 percent of the total to less than $10 \%$ in 2012.

\subsubsection{Groundwater Resources}

After the construction of reservoirs of SIRB, the Irrigation canal system gradually lining gradually. The surface water resources full realization artificial control, surface water use efficiency increased gradually, thus decreasing groundwater recharge sources, resulting in a significant decline in the water table of mid-downstream, and spring flows decreasing gradually.

Before reservoir construction, the spring runoff amounted in the Wuwei Basin of midstream more than 800 million $\mathrm{m}^{3}$ and the total number of spring is 291. By the year 2000, 230 spring have been dried and the spring water spill belt moved back to the upper reaches $2-5 \mathrm{~km}$, the spring runoff reduce to 100 million $\mathrm{m}^{3}$; And the spring in the Jinchang and Minqin Basin of downstream had dried up as early as 1965 around [9] (Sun et al., 2009). After 1980, SIRB began continuous large-scale land reclamation nearly 20 years, large area of grassland have been reclaimed as farmland, Limited surface water resources cannot meet the sharp increase of irrigation water demand, So a large number of wells was drilling to exploitation of groundwater for irrigation, it resulted basin groundwater rapid decline., And then formed several underground water subsidence funnels. Figure 3: the groundwater level of Shuangshu and Daliu in Wuwei midstream dropped from around $5 \mathrm{~m}$ to around $10 \mathrm{~m}$ in 20 years from 1981 to 2001, While in Minqin dam region of downstream area it down faster, down from $8.52 \mathrm{~m}$ to $22.68 \mathrm{~m}$ in 20 years. Downstream Minqin Chungxhing due Hongyashan reservoir is located here, and Minqin Shoucheng area wells and wasteland little, little change in groundwater. Until 2001, the government noted that a 


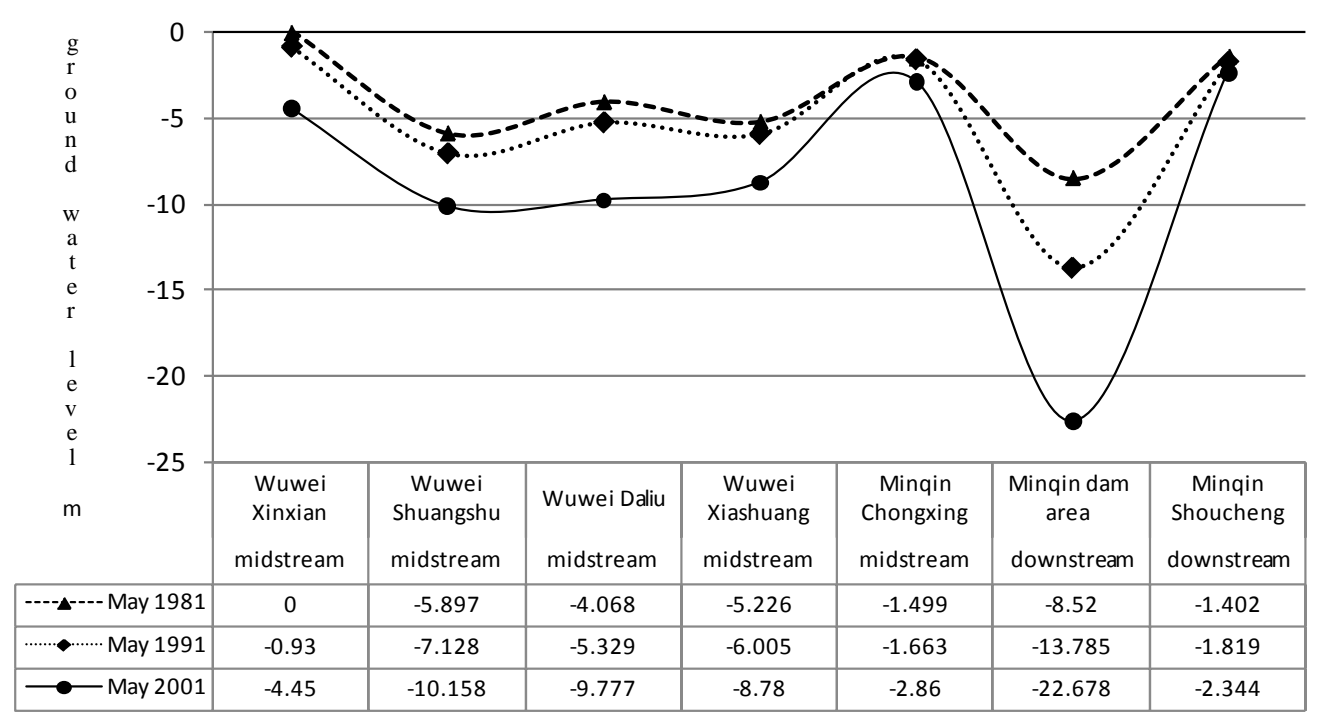

Figure 3. The groundwater level between midstream and downstream from 1981 to 2011 in Shiyang river.

lot of exploitation of groundwater caused to serious ecological damage, Government began to ban drilling well and land reclamation, while abandon wells and reduce field, and carried out from the outer basin water transfer project, so the Groundwater fell of all Basin under control, to 2011 groundwater level basically were flat with 2001.

\section{Discuss}

\subsection{Water Fact Is the Most Important Constraint of the Use of Land and Water Resources in SIRB}

The water resource of SIRB shortage, total amount is about 1.539 billion $\mathrm{m}^{3}$, according to the existing population per $755 \mathrm{~m}^{3}$; it is a typical resource-based dryland area. The maximum possible utilization of total water resources is $75.7 \%$, so the net amount of water the maximum possible use is 1.165 billion $\mathrm{m}^{3}$. Deduct 0.50 million $\mathrm{m}^{3}$ drinking and other life water, and 131 million $\mathrm{m}^{3}$ industrial consumption volumes, the net water volume can be used for agricultural and ecological is 984 million $\mathrm{m}^{3}$ [10] [11] (Zhang et al., 2007; Han et al., 2007). Accordance with net water consumption rating $4500 \mathrm{~m}^{3} / \mathrm{hm}^{2}$, the possible irrigation area is $218,700 \mathrm{hm}^{2}$. While the arable land of SIRB continues to grow from the beginning of the 1970s, to 2010 the arable land has reached $585,000 \mathrm{hm}^{2}$, exceed the greatest burden of water area more than doubled. The area overloading can only rely on over-exploitation of groundwater and reuse of water resources to meet the demand for irrigation; it leads to continued predatory exploitation groundwater resources in basin, Water circulation basin has undergone a fundamental change, river basin water are on a serious imbalance and become an increasingly prominent with upstream, midstream and downstream, This is a serious threat to the sustainable utilization of the water resources, also Threatening the security of the oasis of entire river basin. In order to make the limited water resources play greater social and environmental benefits, the basin should adjust the industrial structure and develop water saving irrigation, promote a virtuous cycle of water resources, to achieve sustainable development, seek a sustainable development ways conversion natural oasis to artificial oasis efficiency in arid zone.

\subsection{Water Resources Determines the Ecological Environment of Inland River Basin}

As a typical arid inland river basin, SIRB water resources development and utilization caused a series ecological change, some can be avoided, and some will inevitably. It should not be undue emphasis on ecological protection, so that the natural balance of the ecosystem back to the inefficiencies of view is unrealistic. Dam construction and Water delivery project have changed the pattern of the basin water cycle, reduced groundwater recharge, dried up Rivers, reduced river, and cut spring. Continued over-exploitation of groundwater has led to a substantial decline in regional groundwater and Increased salinity. The original development of the forest, grassland and 
shrub along the banks rapidly degraded even disappear, swamp and water-loving vegetation distribution along with a wide spring overflow decline with the decrease spring, replaced by a xeric, Sand and salt meadow, the vegetation ecosystem decline and the ecological environment Serious deterioration. Water resources developments have a decisive influence on fragile ecosystems of arid inland river basin, There is an oasis with water, dry desert no water, more water Stalinization. It is also not one-sided pursuit economic efficiency in water resources development, but should be the principle of ecological sustainability priority, In pursuit of a unified ecological and economic efficiency. We should rational allocation water resource accordance with the principle of "water to irrigate land, water to the population and water to develop scale"; according to the viewpoint that Watershed is a perfect interconnected ecosystem of surface and groundwater, to overall coordination the water relationship between upstream and downstream, and coordination water relations between agriculture, forestry, animal husbandry, ecology and mining and urban, Surface water and groundwater joint development relationship, also Surface water and groundwater joint development relationship, to achieve sustainable and efficient use of water resources.

\section{Acknowledgments}

This work was supported by the National Natural Science Foundation of China (41061046, 31360204), the Natural Science Foundation of GanSu province (1506RJZA137).

\section{References}

[1] Qi, Y.A., Li, J.J, Zhang, J.M., et al. (2006) Research on Eco-Functional Regionalization in Shiyang River Basin. Journal of Lanzhou University (Natural Sciences), 42, 29-33.

[2] Ji, Y.F., E, Y.H., Yang, Z.H., et al. (2008) Study on the Ecological Functional Divisions and Ecological Water Consumption in the Minqin Basin. Arid Zone Research, 25, 10-15. http://dx.doi.org/10.3724/SP.J.1148.2008.00010

[3] Guo, C.L. and Li, F.M. (2010) Ecological Problem and Its Rehabilitation Countermeasures in Shiyang River Basin. Journal of Desert Research, 30, 608-613.

[4] Xu, Z.X. and Zuo, M.F. (1989) The Influence of Water Resource Development on the Ecological Environment in Shiyang River Basin. Natural Resource, No. 5, 33-36.

[5] Xu, Z.X. and Zuo, M.F. (1986) The Influencing Factors and Dynamic Law of Groundwater in Shiyang River Basin. Groundwater, No. 4, 31-35.

[6] Han, L.Y., Wang, B.J. and Zhang, Z.S. (2008) Remote Sensing Based Dynamic Monitoring on Change of Vegetation Cover in Shiyanghe River Watershed. Pratacultural Science, 25, 11-15.

[7] Wang, G.X., Chen, G.D. and Chen, Y.P. (2002) Features of Eco-Environmental Changes in Hexi Corridor Region in the Last 50 Years and Comprehensive Control Strategies. Journal of Natural resources, 17, 78-86.

[8] Han, L.Y., Han, T. and Zhang, Z.S. (2009) Monitoring on Water Resource and Ecological Environment in Shiyanghe River Basin through Remote Sensing in 10 years. Pratacultural Science, 26, 46-51.

[9] Sun, Y., Mao, X.M. and Shen, Q.L. (2009) Temporal and Spatial Variations of Groundwater Depth in Shiyang River Basin. Journal of Arid Land Resources and Environment, 23, 112-117.

[10] Zhang, T.Z., Cai, H.J. and Wang, X.J. (2007) Analysis for the Evolution Rule of Water Resources in Shiyanghe River Basin. Journal of Water Sources and Water Engineering, 18, 23-27.

[11] Han, F.J. and Zhang, B. (2007) Analysis on the Characteristic Changes of the Eco-Environment and Water Resources in Shiyang River Catchments. Journal of Safety and Environment, 17, 80-83. 


\section{Submit or recommend next manuscript to SCIRP and we will provide best service for you:}

Accepting pre-submission inquiries through Email, Facebook, LinkedIn, Twitter, etc.

A wide selection of journals (inclusive of 9 subjects, more than 200 journals)

Providing 24-hour high-quality service

User-friendly online submission system

Fair and swift peer-review system

Efficient typesetting and proofreading procedure

Display of the result of downloads and visits, as well as the number of cited articles

Maximum dissemination of your research work

Submit your manuscript at: http://papersubmission.scirp.org/ 